\title{
Disturbances in groundwater chemical parameters related to seismic and volcanic activity in Kamchatka (Russia)
}

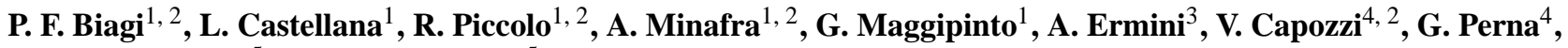 \\ Y. M. Khatkevich ${ }^{5}$, and E. I. Gordeev ${ }^{5}$ \\ ${ }^{1}$ Department of Physics, University of Bari, Via Amendola, 173, 70126 Bari, Italy \\ ${ }^{2}$ INFM-Unity of Bari, Bari, Italy \\ ${ }^{3}$ Department of Engineering of Enterprise, University of Roma Tor Vergata, Via di Tor Vergata, 00133 Rome, Italy \\ ${ }^{4}$ Department of Biomedical Sciences, University of Foggia, Via L. Pinto, 71100 Foggia, Italy \\ ${ }^{5}$ Experimental and Methodical Seismological Department, Geophysical Service Russian Academy of Science, Pijp Av. 9, \\ Petropavlovsk-Kamchatsky 683006, Russia
}

Received: 16 June 2004 - Revised: 22 September 2004 - Accepted: 23 September 2004 - Published: 27 September 2004

Part of Special Issue "Precursory phenomena, seismic hazard evaluation and seismo-tectonic electromagnetic effects"

\begin{abstract}
Starting from 1992 geochemical data are being collected with a mean sampling frequency of three days in the form of the $\mathrm{pH}$ value and of the most common ions and gases in the groundwater in one deep well located in Petropavlovsk, the capital city of Kamchatka (Russia). On 1 January 1996 a strong eruption started from the Karymsky volcano, that is located about $100 \mathrm{~km}$ far from the well, in the north-northeastern direction. At the same time, a large earthquake ( $M=6.9)$ occurred in the Karymsky area. On 5 December 1997 a very large earthquake $(M=7.7)$ occurred offshore, at a distance of $350 \mathrm{~km}$ from the well and towards the same direction. The analysis of the geochemical data shows clear variations in the raw temporal trends on both cases. For the first event, a clear premonitory phase appeared; for the second one, some pre-seismic variations could be revealed but permanent modifications of the chemistry of the water subsequent to the earthquake are very clear. In both cases the feature of the geochemical variations is consistent with an afflux of new water in the aquifer connected with the well and with an escape of the Carbon dioxide gas from the ground in different directions. A schematic model able to justify such a phenomenology and the connections of the geochemical variations with the previous tectonic activities is proposed.
\end{abstract}

\section{Introduction}

Geochemical data in the water of springs and wells in the Kamchatka peninsula have been collected by the Geophysical Service of Kamchatka (Russia) since 1977. A cooperation programme between Italian researchers and re-

Correspondence to: P. F. Biagi

(biagi@fisica.uniba.it) searchers of the Geophysical Service of Kamchatka (Russia) started in 1995 and it is still operating. As a result of this Italian-Russian co-operation, a data bank has been established containing all the Kamchatka geochemical data collected which can be compared with the seismic catalogue of the Seismological Service of Kamchatka. Meanwhile, the study of the relationship between the hydro-geochemical data and seismicity began and several results were reported (Bella et al., 1998; Biagi et al., 1999a, b, 2000a, b, 2001a, b, c, 2004; Kingsley et al., 1999).

Here we present the analysis of the geochemical data that were collected in one deep well of the network, in order to point out the relationship between some disturbances in the temporal trends of the raw data and the volcanic and seismic activity occurred in the north-northeastern area with respect to the well.

\section{Seismicity and measurement site}

The Kamchatka peninsula is an active area where the Pacific plate subducts at north beneath the north American plate and at south beneath the Eurasia plate. More than 80 volcanoes exist and many of them are active. In the seismic point of view, we can distinguish the south area of the peninsula in two different zones, one located offshore $60-100 \mathrm{~km}$ far from the Pacific coast and the other in the continental part. The majority of earthquakes occur in the first zone with focal depths up to $650 \mathrm{~km}$. The strongest one in the last 15 years happened on 5 December 1997 with magnitude $M=7.7$ and focal depth of $10 \mathrm{~km}$. The location of the epicentre is indicated in Fig. 1. About 80 earthquakes with magnitude $\mathrm{M}=4.0-5.0$ defined the foreshock activity from 1 December. The aftershock activity went on for one year with more than 2000 earthquakes (with largest magnitude equal to 6.8). In 


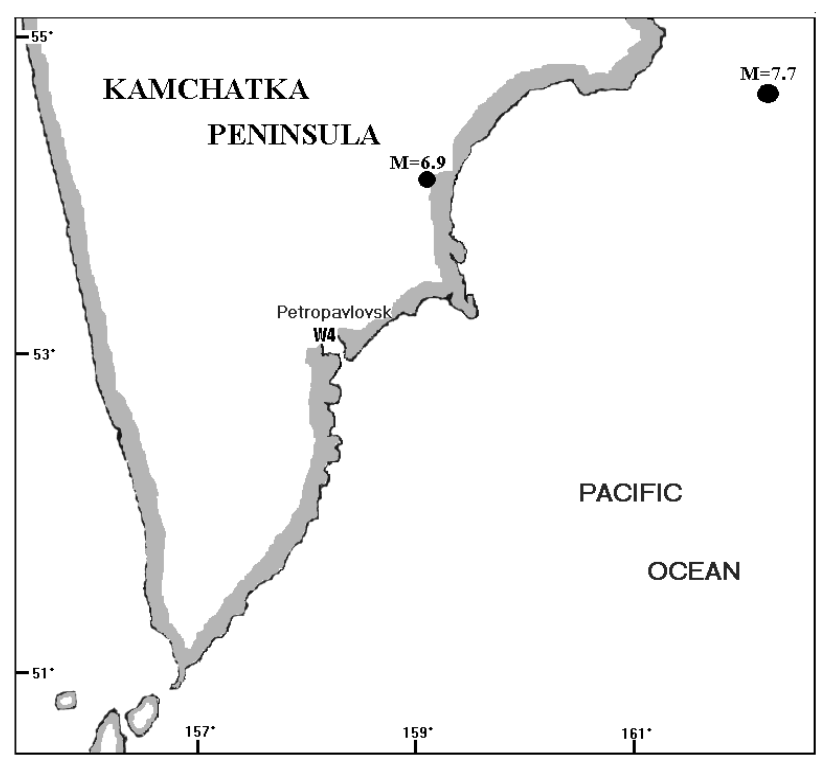

Fig. 1. Map showing the southern part of the Kamchatka peninsula and the location of the $\mathrm{W}_{4}$. The black circles indicate the epicentres of the 1 January 1996 earthquake $(M=6.9)$ and of the 5 December 1997 earthquake $(\mathrm{M}=7.7)$.

the continental part of southern Kamchatka the frequency of earthquakes is lesser than that in the offshore zone and the genesis is different, too: the earthquakes are mainly volcanic events and their magnitude rarely exceeds 5.5. An exception was the earthquake that occurred on 1 January 1996 (Fig. 1) with magnitude $\mathrm{M}=6.9$ and focal depth of $2 \mathrm{~km}$, that is considered a tectonic earthquake (Gordeev et al., 1998). The foreshock activity (with largest magnitude equal to 5.2) started few hours before the main shock. The aftershock activity went on for two months with about 800 earthquakes (with largest magnitude equal to 6.4); then some single earthquake occurred till the end of the year. Almost simultaneously with the main shock, a volcanic eruption took place in the central crater of Karymsky volcano, $15 \mathrm{~km}$ far from the earthquake epicentre. Many evidences indicate that the earthquake and the volcanic eruption were separate events (Gordeev et al., 1998).

The well under study, named $\mathrm{W}_{4}$, is located in Petropavlovsk, the capital city of Kamchatka (Fig. 1) and the water is not flowing from the well. Some main characteristics of the well are listed in Table 1. Since 1992, the $\mathrm{pH}$ value, the ion content $\left(\mathrm{Na}^{+}, \mathrm{Ca}^{++}, \mathrm{Cl}^{-}, \mathrm{HCO}_{3}^{-}, \mathrm{SO}_{4}^{--}\right)$and the gas content (total, $\mathrm{CO}_{2}, \mathrm{Ar}, \mathrm{N}_{2}$ ) are being measured in water samples that are collected from this well every three days on the average. The content of dissolved gases is measured by means of gas chromatography, after thermovacuum degassing; the $\mathrm{Na}^{+}$and $\mathrm{Ca}^{++}$concentration is measured by flame emission spectrometry; the $\mathrm{Cl}^{-}, \mathrm{HCO}_{3}^{-}$, and $\mathrm{SO}_{4}^{--}$ concentration by titration methods and the $\mathrm{pH}$ value by $\mathrm{pH}$ meter. The accuracy of the measurements ranges from $2 \%$ to $10 \%$.

\section{Results}

First, we derived continuous data sets with one value per day by linear interpolation of the raw geochemical data collected at $\mathrm{W}_{4}$. As an example some trends are reported in Fig. 2. It is possible to note that disturbances appear on the trends in three different time periods: period a (1995-1996), period b (1997-1998) and period c (1999-2000). The disturbances in the period $\mathrm{c}$ are related to a human activity that is the installing, $1000 \mathrm{~m}$ deep in the well, of an ULF acoustic sensor in order to perform a new experiment. So, these disturbances can be ignored in this study. Figures 3 and 4 show in details the parameters in the trend of which the disturbances during the period $\mathrm{a}$ and $\mathrm{b}$ appear more clearly. In Fig. 3, a vertical dashed line indicates the time occurrence of the 1 January 1996 earthquake (M=6.9, Fig. 1) and the beginning of the Karymsky volcano eruption. A variation which is evident in all parameters appears, starting about three months before the events and lasting no more than some weeks after their occurrence. Afterwards, the average content of the geochemical parameters returns to the previous values. In Fig. 4, a vertical line represents the occurrence of the 5 December 1997 earthquake ( $M=7.7$, Fig. 1). With respect to the previous period, it is possible to note that the most relevant and strong effect is a long and evident drift of each trend up to a new stable average level, different from that before the earthquake. The drift starts about six months before the earthquake occurrence and its interpretation as a pre-seismic variation is not immediately evident: probably it can be related to the earthquake only with "a posteriori" approach. The new level is reached a long time after the earthquake (in some cases more than one year). So, a permanent change in the chemistry of $\mathrm{W}_{4}$ appears.

\section{Discussion}

In the previous section, we identified two different time periods ( $a$ and $b$ ) in which some perturbations in the geochemical parameters at $\mathrm{W}_{4}$ occurred and a clear connection between these disturbances and natural (volcanic and seismic) events seems to come out.

First, let us examine the perturbation during the time period a. From Fig. 3 it is possible to note that the permanent perturbation is mainly characterized by a decrease in the $\mathrm{Cl}^{-}$ and $\mathrm{Na}^{+}$contents, i.e. a decrease of the water salinity, by a decrease in $\mathrm{Ca}^{++}, \mathrm{SO}_{4}^{--}$and $\mathrm{CO}_{2}$ contents and by an increase of the $\mathrm{pH}$ value. These features are consistent with: 1 ) an afflux in the aquifer connected with the well of fresh water (small salinity) and with a smaller quantity of carbonates and sulphates (from the ionic dissociation of which the $\mathrm{Ca}^{++}$ and $\mathrm{SO}_{4}^{--}$ions come); 2) a reduction of the $\mathrm{CO}_{2}$ contribution from the ground (reservoir for the aquifer) producing a consequent $\left[\mathrm{CO}_{2}+\mathrm{H}_{2} \mathrm{O} \leftrightarrow \mathrm{H}_{2} \mathrm{CO}_{3}\right.$ (carbonic acid)] decrease of the water acidity, i.e. an increase of the $\mathrm{pH}$ value.

Now, let us examine the perturbation in the geochemical parameters at $\mathrm{W}_{4}$ during the time period b. From Fig. 4 it is 
Table 1. Drilling time, depth and cross-section of $\mathrm{W}_{4}$.

\begin{tabular}{cccc}
\hline DRILLING & DEPTH $(\mathrm{m})$ & & CROSS-SECTION \\
\hline $1986-1988$ & 2542 & $0-109 \mathrm{~m}$ & sandy-argillaceous, rubbly-pebbled deposits \\
& & $109-520 \mathrm{~m}$ & aleurolite \\
& & $520-591 \mathrm{~m}$ & andesite \\
& $91-734 \mathrm{~m}$ & diorite \\
& & $734-1897 \mathrm{~m}$ & interbedding of argillite, shale and aleurite \\
& & $1897-2542 \mathrm{~m}$ & succession of diorites and argillite \\
& &
\end{tabular}

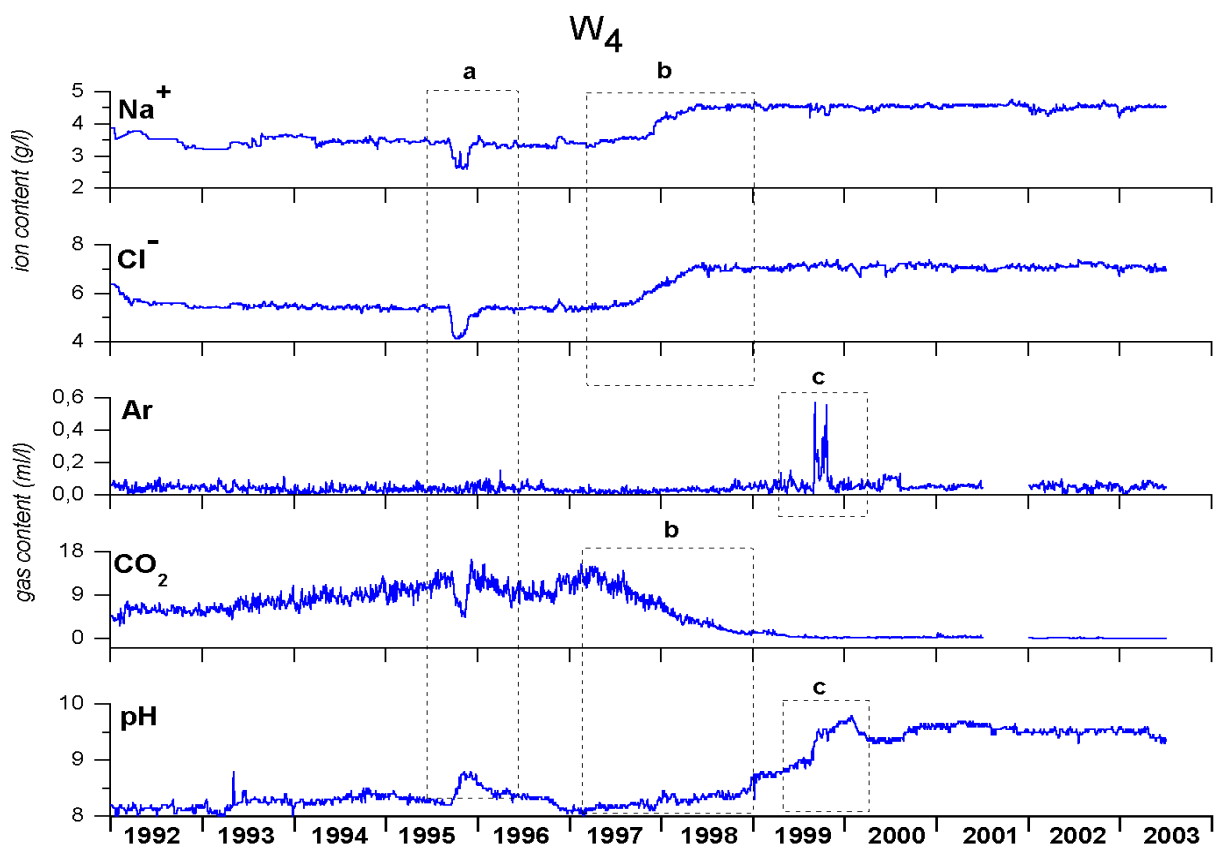

Fig. 2. Time-series of $\mathrm{Na}^{+}$and $\mathrm{Cl}^{-}$ion contents, of $\mathrm{Ar}$ and $\mathrm{CO}_{2}$ gas contents and of $\mathrm{pH}$ value at $\mathrm{W}_{4}$ from $1 \mathrm{January} 1992$ to $30 \mathrm{June} 2003$. Clear disturbances stand up in 1995-1996 (period a), in 1997-1998 (period b) and in 1999-2000 (period c).

possible to note that the perturbation, that is a permanent one, is mainly characterized by an increase in the $\mathrm{Cl}^{-}$and $\mathrm{Na}^{+}$ contents, i.e. an increase of the water salinity, by a decrease in the $\mathrm{HCO}_{3}^{-}$and $\mathrm{CO}_{2}$ contents and by an increase of the $\mathrm{pH}$ value. Following the previous considerations, these features are consistent with: 1) an afflux of salt water (great salinity) in the aquifer; 2) a reduction of the $\mathrm{CO}_{2}$ contribution from the ground. Note that the observed decrease in $\mathrm{HCO}_{3}^{-}$content is connected with the decrease of the carbonic acid, from the ionic dissociation of which this ion comes.

We have looked for an explanation of the observed geochemical disturbances and we think that they could be justified, in both cases, by an increase of the stress/strain happened in the area of the aquifer connected with the well. Such an increase produced an intensification of micro-fracturing processes and/or changes in existing cracks in the rocks surrounding the aquifer. As a consequence, at first the $\mathrm{CO}_{2}$ gas escaped from the ground along different directions reducing its contribution to the aquifer. Then, water with different salinity and, in the first case with a smaller amount of
Calcium carbonate and sulphate, with respect to the previous one, rushed to the aquifer across the new fissures and cracks. In the period a, the local tectonics was able to readjust the underground system to the pre-existing conditions, when the increase of the stress/strain in the area of the aquifer finished. Such a readjustment did not appear in the period $b$.

We think that the subduction motion of the Pacific plate under the Eurasia plate underwent some changes that produced the previous stress/strain increases. So, such increases occurred on a large scale in the southern-east area of the peninsula, where the plates margin is located. In the zone of the aquifer under study they caused only transient (period a) or permanent (period b) modifications in the fissures and cracks of the rocks surrounding the aquifer. On the contrary in the zones where the underground conditions were near to the breaking point and where it can be supposed that the stress/strain increases were greatest, a volcanic eruption and large earthquakes were generated.

It must be noted that no disturbances in the geochemical data of $\mathrm{W}_{4}$ were revealed on the occasion of the earthquakes 


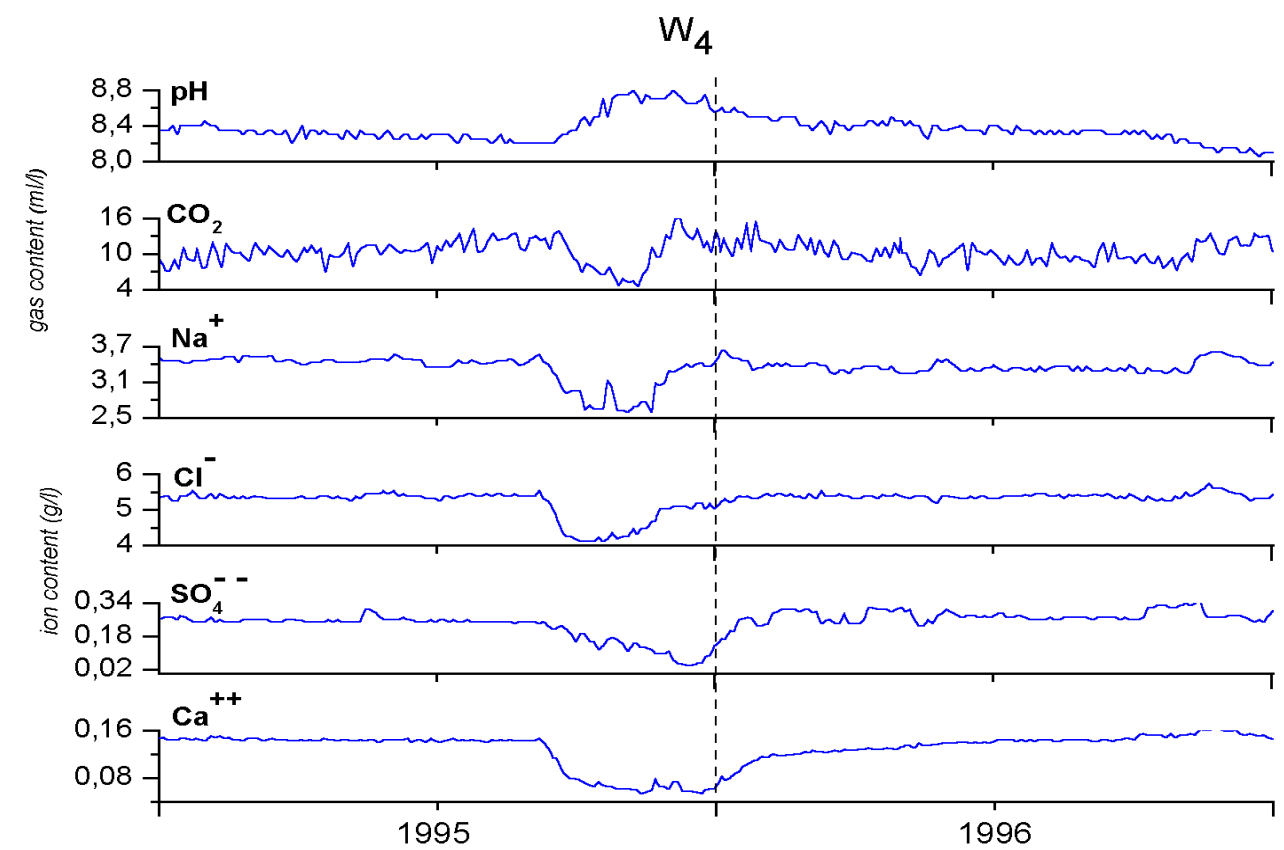

Fig. 3. From the top to the bottom, the $\mathrm{pH}$ value, the $\mathrm{CO}_{2}$ gas content and the $\mathrm{Na}^{+}, \mathrm{Cl}^{-}, \mathrm{SO}_{4}^{--}$and $\mathrm{Ca}^{++}$ion contents at $\mathrm{W}_{4}$ from 1 January 1995 to 31 December 1996. The vertical line indicates the occurrence of the 1 January 1996 earthquake (M=6.9) and the beginning of the Karymsky volcano eruption.

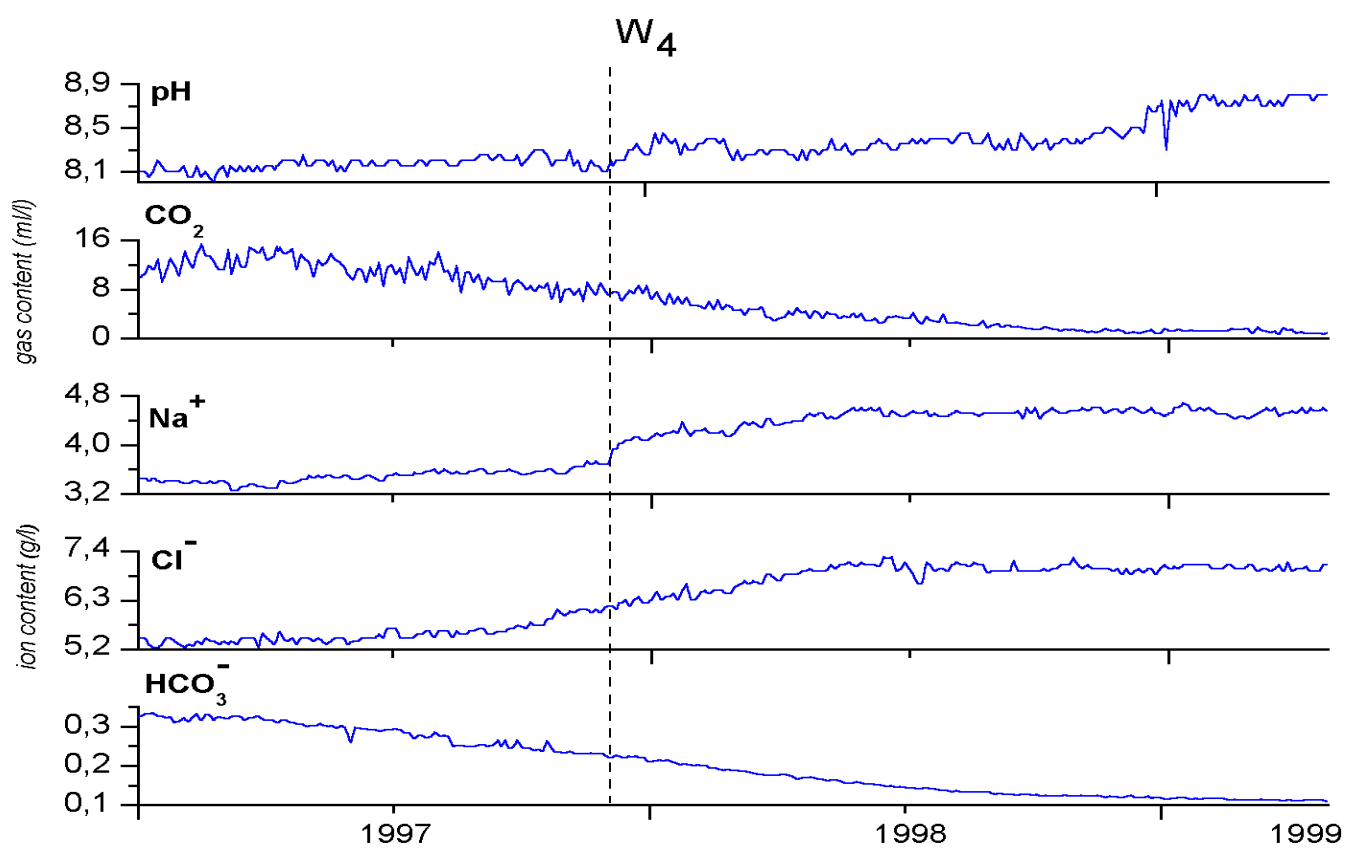

Fig. 4. From the top to the bottom, the $\mathrm{pH}$ value, the $\mathrm{CO}_{2}$ gas content and the $\mathrm{Na}^{+}, \mathrm{Cl}^{-}$and $\mathrm{HCO}_{3}^{-}$ion contents at $\mathrm{W}_{4}$ from $1 \mathrm{January} 1997$ to 30 April 1999. The vertical line indicates the occurrence of the 5 December 1997 earthquake (M=7.7).

of large magnitude ( $\mathrm{M}=7.0-7.3)$ occurred in the 1992-2003 period at east-south east (Fig. 1) with respect to the well. So, the sensitivity of this well is related only to the tectonic processes occurring at north-northeastern direction with respect to its location. It means that some structural underground connection exists along this direction.

\section{Conclusions}

We presented some anomalies in the geochemical parameters at one well, related with volcanic and seismic events occurred $100-350 \mathrm{~km}$ far from the well. A premonitory phase appears clearly only some times. We proposed a 
large scale stess/strain increase of a common genesis able to produce the geochemical anomalies and the natural events. According to our opinion, such an assumption is consistent with the intense tectonic processes involving the Kamchatka peninsula. In such a way the presence of anomalies in geochemical parameters so far from the epicentres can be justified.

Edited by: M. Contadakis

Reviewed by: two referees

\section{References}

Bella, F., Biagi, P. F., Caputo, M., Cozzi, E., Della Monica, G., Ermini, A., Gordeev, E. I., Khatkevich, Y. M., Martinelli, G., Plastino, W., Scandone, R., Sgrigna, V., and Zilpimiani, D.: Hydrogeochemical anomalies in Kamchatka (Russia), Physics and Chemistry of the Earth, 23, 921-926, 1998.

Biagi, P. F., Bella, F., Cozzi, E., Ermini, A., Scandone, R., Khatkevich, Y. M., Gordeev, E. I., Kingsley, S. P., Anderson, C. W., and Derlien, P. J.: Groundwater Argon content on the occasion of strong earthquakes in a seismogenetic area of Kamchatka (Russia), Il Nuovo Cimento C, 22, 503-508, 1999.

Biagi, P. F., Bella, F., Ermini, A., Cozzi, E., Gordeev, E. I., and Khatkevich, Y. M.: Hydrogeochemical precursors in Kamchatka (Russia) related to the strongest earthquakes in 1988-1997, Natural Hazards, 21, 263-276, 2000a.
Biagi, P. F., Ermini, A., Kingsley, S. P., Khatkevich, Y. M., and Gordeev, E. I.: Groundwater ion content precursors of strong earthquakes in Kamchatka (Russia), Pure and Applied Geophysics, 157, 302-320, 2000b.

Biagi, P. F., Ermini, A., Kingsley, S. P., Khatkevich, Y. M., and Gordeev, E. I.: Difficulties with interpreting changes in groundwater gas content as earthquake precursors in Kamchatka (Russia), Journal of Seismology, 5, 487-497, 2001a.

Biagi P. F., Kingsley, S. P., Piccolo, R., Capozzi, V., Ermini, A., Khatkevich, Y. M., and Gordeev, E. I.: Hydrogeochemical precursors of strong earthquakes: a realistic possibility in Kamchatka, Physics and Chemistry of the Earth, 26, 769-774, $2001 \mathrm{~b}$.

Biagi, P. F., Piccolo, R., Ermini, A., Fujinawa, Y., Kingsley, S. P., Khatkevich, Y. M., and Gordeev, E. I.: Hydrogeochemical precursors of strong earthquakes in Kamchatka: further analysis, Natural Hazards and Earth System Sciences, 1, 9-14, 2001c, SRef-ID: 1684-9981/nhess/2001-1-9.

Biagi, P. F., Piccolo, R., Minafra, A., Maggipinto, T., Castellana, L., Molchanov, O., Ermini, A., Capozzi, V., Perna, G., Khatkevich, Y. M., and Gordeev, E. I.: Retrospective analysis for detecting seismic precursors in groundwater argon content, Natural Hazards and Earth System Sciences, 4, 9-15, 2004,

SRef-ID: 1684-9981/nhess/2004-4-9.

Gordeev, E. I., Droznin, D. V., Kasahara, M., Levina,, V. I., Leonov, V. L., Miyamachi, H., Okayama, M., Saltykov, V. A., Sinitsyn, V. I., and Chebrov, V. N.: Seismic Events Associated with the 1996 Volcanic Eruptions in the Karymsky Volcanic center, Volcanology and Seismology, 19, 713-735, 1998.

Kingsley, S. P., Anderson, C. W., Biagi, P. F., Derlien, P. J., Ermini, A., Gordeev, E. I., and Khatkevich, Y. M.: Analysis of Argon concentration anomalies in underground water in Kamchatka (Russia), Il Nuovo Cimento C, 22, 407-413, 1999. 